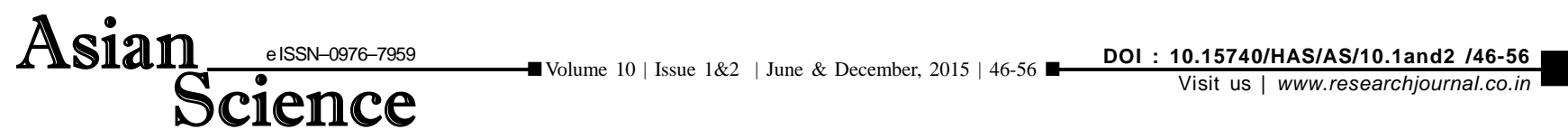

A CASE STUDY

\title{
Study of constitution meaning and types of constitution
}

\author{
SHRIYA SINGH* AND HEMANGINI SHAH \\ Department of Law, New Law College, Bharati Vidyapeeth, PUNE (M.S.) INDIA
}

Key Words : Constitution meaning, Types, Constitution

View point paper : Singh, Shriya (2015). Study of constitution meaning and types of constitution. Asian Sci., 10 (1\&2): 46-56.

E very state has a fundamental law which is called the constitution or the law of the land. The term constitution is derived from the Latin word 'Constitute' which means to 'To Establish'. The constitution is the basic document of the state. The constitution outlines the power, ambit of work, basic structure etc. of the Government. The Government functions as per the rules and guide lines laid down in the constitution.

A constitution is a set of laws and rules setting up the machinery of the Government of a state and which determines the relationship between different organs of the Government. Summarily a constitution is the source, the jurisprudential fountain head from which all the other laws must flow. The first written constitution was that of United States of America. India has the longest written constitution in the world. United Kingdom has an unwritten constitution.

\section{Meaning and definition of constitution :}

Various political thinkers and jurist have given varied definitions of the constitution.
Aristotle:

Constitution is the way of life the state has chosen for itself (Mahajan, 2003).

\section{Bouvies:}

"The fundamental law of a state, directing the principles upon which the government is founded and regulating the exercise of the sovereign powers, directing to what bodies or person these powers shall be confined and the manner of their exercise" (Asirvatham and Misra, 2006).

\section{Austin:}

"Constitution fixes the structure of Supreme Government" (Mynemi, 2006).

\section{Colley :}

"The fundamental law of the state containing the principles upon which Government is founded regulating the division of the sovereign powers and directing to what persons each of these powers is to be confined and the manner in which it is to be exercised" (Ibid).

\footnotetext{
* Author for correspondence

Shriya Singh, Department of Law, New Law College, Bharati Vidyapeeth, PUNE (M.S.) INDIA (Email: shriya.law@ gmail.com)
} 